\title{
The role of porous matrix in water flow regulation within a karst unsaturated zone: an integrated hydrogeophysical approach
}

\author{
Simon D. Carrière ${ }^{1 *}$, Konstantinos Chalikakis ${ }^{2}$, Charles Danquigny ${ }^{1}$, Hendrik Davi ${ }^{3}$, Naomi Mazzilli ${ }^{2}$,
} Chloé Ollivier ${ }^{2}$, Christophe Emblanch ${ }^{2}$

1. UMR 1114 EMMAH, INRA, Domaine Saint Paul, Site Agroparc, 84914 Avignon, France

Email: simon.carriere@paca.inra.fr

2. UMR 1114 EMMAH, UAPV, 301 rue Baruch de Spinoza BP 21239, 84916 Avignon, France

3. UR629, URFM, INRA, Domaine Saint Paul, Site Agroparc, 84914 Avignon, France

* corresponding author

\section{Abstract:}

Some portions of the porous rock matrix in the karst unsaturated zone (UZ) can contain large volumes of water and play a major role in water flow regulation. The essential results are presented of a local-scale study conducted in 2011 and 2012 above the Low Noise Underground Laboratory (LSBB - Laboratoire Souterrain à Bas Bruit) at Rustrel, southeastern France. Previous research revealed the geological structure and water-related features of the study site and illustrated the feasibility of specific hydrogeophysical measurements. In this study, the focus is on hydrodynamics at the seasonal and event time scales. Magnetic resonance sounding (MRS) measured a high water content (more than $10 \%$ ) in a large volume of rock. This large volume of water cannot be stored in fractures and conduits within the UZ. MRS was also used to measure the seasonal variation of water stored in the karst UZ. A process-based model was developed to simulate the effect of vegetation on groundwater recharge dynamics. In addition, electrical resistivity tomography (ERT) monitoring was used to assess preferential water pathways during a rain event. This study demonstrates the major influence of water flow within the porous rock matrix on the UZ hydrogeological functioning at both the local (LSBB) and regional (Fontaine de Vaucluse) scales. By taking into account the role of the porous matrix in water flow regulation, these findings may significantly improve karst groundwater hydrodynamic modelling, exploitation, and sustainable management. 


\section{Introduction}

Karstified rocks cover a large portion of the world's surface (Gunn 2004), particularly around the Mediterranean Sea (Bakalowicz and Dörfliger 2005). Unfortunately the complexity of karst hydrosystems continues to impede sustainable water exploitation and management (e.g. Mangin 1975; Bakalowicz 1995; Ford and Williams 2007; Goldscheider and Drew 2007; White 2007). In the context of climate change, additional stress on water resources may require more intense exploitation of karst hydrosystem water resources. These factors and sustainable management require improved knowledge about how karst hydrosystems function.

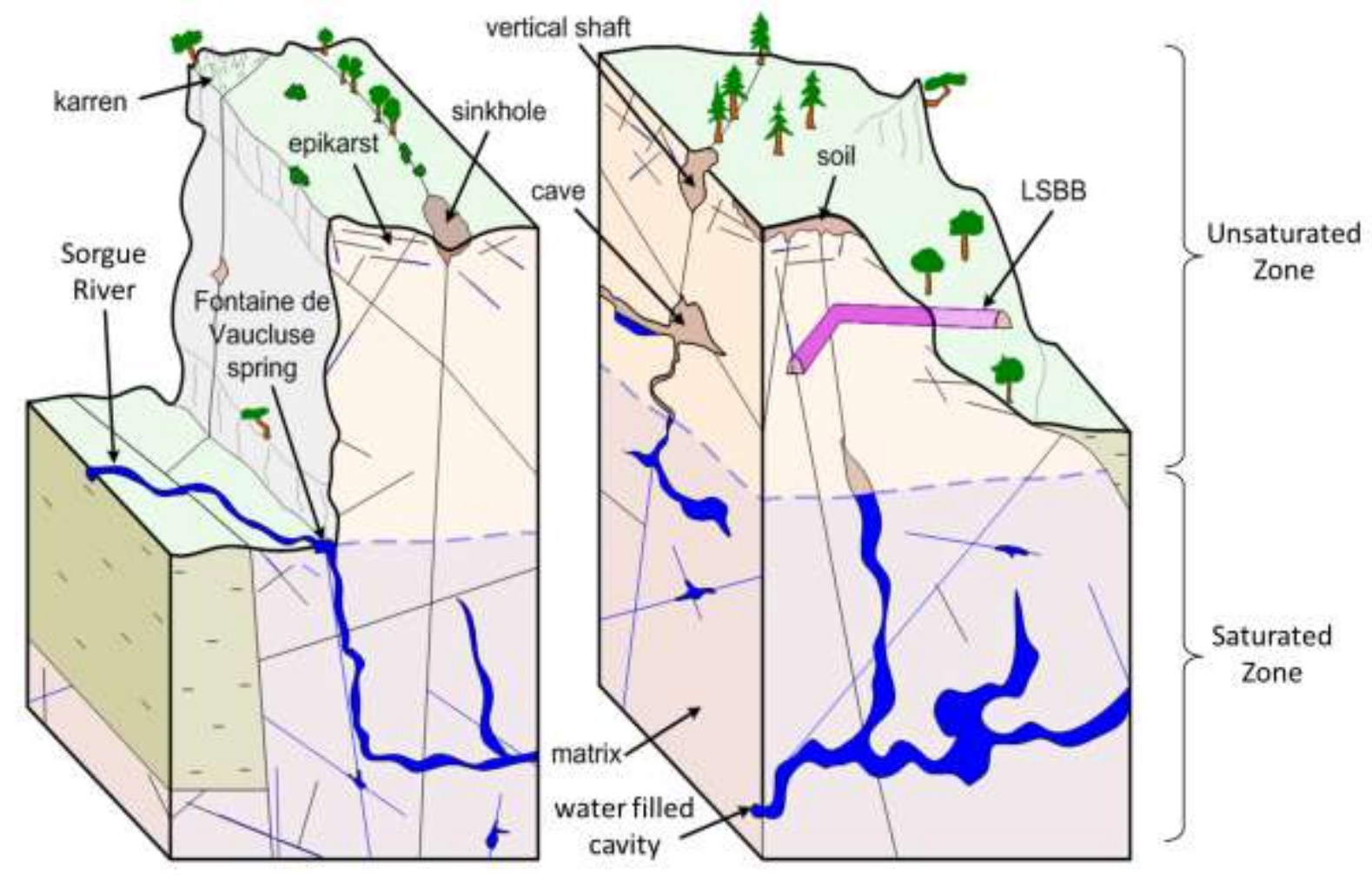

Fig. 1: Karst system model showing the Fontaine de Vaucluse hydrosystem and the Low Noise Underground Laboratory of Rustrel (LSBB).

Karst is a complex medium with multi-scale heterogeneity. Water flow pathways are present throughout the entire medium, from rock matrix to fractures and karst features (Fig. 1). The hydrodynamic role of these water pathways is still poorly understood (e.g. Bailly-Comte et al. 2010) and water flow regulation within karst hydrosystems remains an important issue. On one hand, karst 
hydrosystems have high permeability because a large amount of water moves quickly through karst conduits and rapid pressure transfer occurs. On the other hand, karst hydrosystems provide an important buffer effect because spring discharge remains high even during long dry periods, as at the Fontaine de Vaucluse spring in France. Several hypotheses have been advanced to explain the important water flow regulation capacity of karst hydrosystems: (i) significant water storage within the saturated zone in karst conduits (e.g. Mangin 1975; Marsaud 1996); (ii) water storage in the epikarst, (fractured and weathered near-surface karst) (e.g. Aquilina et al. 2006; Ford and Williams 2007); and (iii) delayed infiltration or travel time within the entire unsaturated zone (UZ) (e.g. CelleJeanton et al. 2003; Emblanch et al. 2003; Mudarra and Andreo 2010; Mudarra et al. 2012). However, this regulation capacity within the UZ is not related to identified geological features (e.g. fractures, matrix). Finally, few researchers consider water storage in the UZ zone to be significant enough to play a role in water flow regulation and the capacitive function of karst.

Due to these complexities, distributed hydrogeological modeling of karst systems remains difficult to implement and is not often done (e.g. Kiraly 1998; Larocque et al. 1999; Scanlon et al. 2003; Worthington 2009; Worthington and Ford 2009). The usual approach to karst hydrosystems is the socalled "black box" model (e.g. Mangin 1975; Marsaud 1996; Labat et al. 2000a; Labat et al. 2000b; Rimmer and Salingar 2006; Fleury et al. 2007; Moussu et al. 2011; Hartmann et al. 2012). However, "black box" models are site-specific. The lack of physics and geology in such models makes difficult their transfer from one karst system to another. Moreover, "black-box" modeling (e.g. Fleury et al. 2007) and hydrochemical estimates (e.g. Batiot et al. 2003) have indicated large residence time differences within a single karst hydrosystem.

Most techniques traditionally used in hydrogeology are of limited success in a complex and heterogeneous media such as karst (Bakalowicz 2005). Hydrogeologists often apply techniques commonly used in surface hydrology, such as natural and artificial tracers or rainfall/runoff models. In recent years, surface based geophysics was added to the methodological suite to improve the analysis of spatial and temporal variability of underground properties (Berkowitz 2002). Numerous 
techniques are available, each with its strengths and weaknesses. Chalikakis et al. (2011) proposed a general overview of geophysical methods for karst media and more recently Kaufmann and Deceuster (2014) published an overview on the use of geophysical surveys to detect ghost rock. In recent years, an increasing number of hydrogeophysical projects aimed at studies of karst hydrogeological functioning have appeared (e.g. Jacob et al. 2008; 2009; 2010; Gondwe et al. 2010; Zhu et al. 2011; Deville 2013; Mazzilli et al. 2013).

This paper presents an integrated hydrogeophysical approach based on several ground-based geophysical methods combined with geological and hydrogeological techniques. This integrated approach provides additional insight into karst UZ structure and functioning. It also proposes a conceptual hydrogeological model to explain the multi-annual dynamics of the studied karst hydrosystem. This conceptual model will likely promote additional and more accurate hydrodynamic modeling. The methodological approach was developed and tested in a typical Mediterranean karst hydrosystem observatory: The Fontaine de Vaucluse - Low Noise Underground Laboratory (LSBB) karst watershed.

\section{Experimental site}

\subsection{General geological and hydrogeological context}

The LSBB, a nearly horizontal underground passageway originally dug for military purposes, was converted to a research laboratory in 1997 (Fig. 1 and 2c). It is situated in the Fontaine de Vaucluse hydrosystem karst UZ, in the village of Rustrel. The rock cover over the passageway ranges in thickness from 0 to $519 \mathrm{~m}$ depending on the topography. The general saturated zone of the karst system is approximately $400 \mathrm{~m}$ beneath the LSBB. The $3.8 \mathrm{~km}$ long passageway traverses the karst medium and arbitrarily intersects faults and karst networks. As a result, the passageway also intersects some flow paths in the UZ. Since 2003 more than 61 flow points have been identified and studied within the laboratory. Three of the flow points are permanent and 58 are temporary; they 
are located between approximate depths of 33 m and 440 m (Garry 2007; Blondel 2008; BarbelPerineau 2013).

One permanent flow point is located $33 \mathrm{~m}$ below the surface at the western extremity of the LSBB passageway (Fig. 2c). This point, called "point D," has an average discharge of approximately $130 \mathrm{~mL} / \mathrm{min}$ (Perineau et al. 2011). The flow at point $\mathrm{D}$ is of great hydrogeological interest because it occurs in a featureless zone in a karst environment: no major fault, no apparent karstification (in both surface - exokarst - and at depth); furthermore, it is located several tens of meters below the so-called "epikarst" zone (according to Mangin's schema (Mangin 1975)). However, it presents surprisingly smooth water dynamics compared to other flow points in the LSBB. The flow at D has sometimes increased after a rain event; however at other times flow has remained unchanged after a similar amount of rain (Barbel-Perineau 2013). The geological context associated with this puzzling hydrogeological behavior led to a research focus on the area located above point $D$.

The study site is located within the Fontaine de Vaucluse karst hydrosystem in southeastern France. The Fontaine de Vaucluse is the largest karst spring in Europe; between 1877 and 2004 it produced an average daily outlet discharge of $19 \mathrm{~m}^{3} / \mathrm{s}$ (Cognard-Plancq et al. 2006). The catchment area is approximately $1115 \mathrm{~km}^{2}$ (Fig. 2b) and the karst UZ is particularly thick; its average thickness is approximately $800 \mathrm{~m}$ (Puig 1987). The large size is due to the presence of a nearly $1500 \mathrm{~m}$ thick massive and continuous limestone (Masse 1969; 1976) comprising Necomanian marls to upper Aptian marls. A part of this carbonate platform is composed of reef limestone, which may reach a thickness of approximately $450 \mathrm{~m}$ in the region (Fig. 2d). This reef limestone contains Urgonian facies that are traditionally divided into three sub-divisions: U1, U2, and U3 (Leenhardt 1883). A part of this Urgonian limestone has exceptionally high total matrix porosity for a limestone and it covers at least half of the Fontaine de Vaucluse catchment (e.g. Masse 1969; Léonide et al. 2014). However, the role of this porosity in water dynamics is still unknown. 


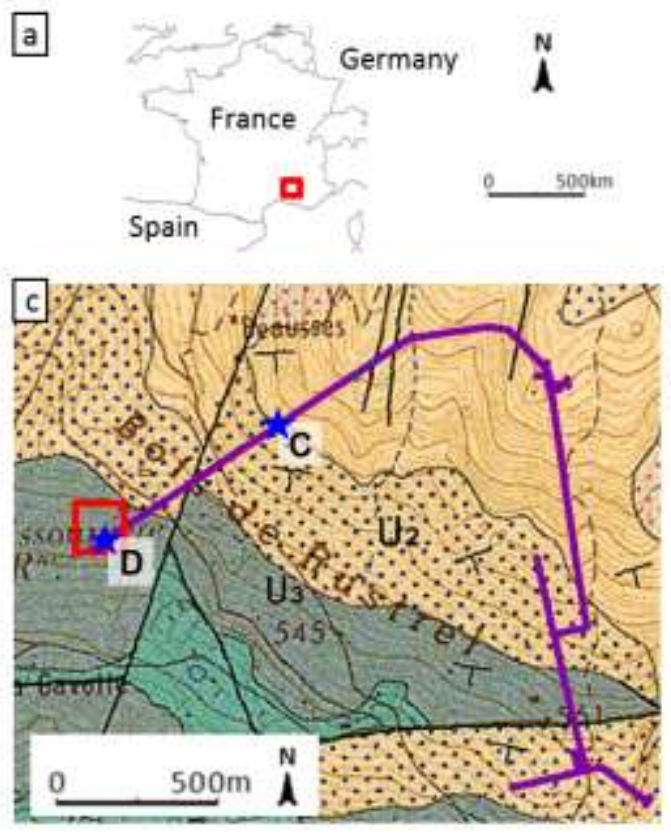

Legend:

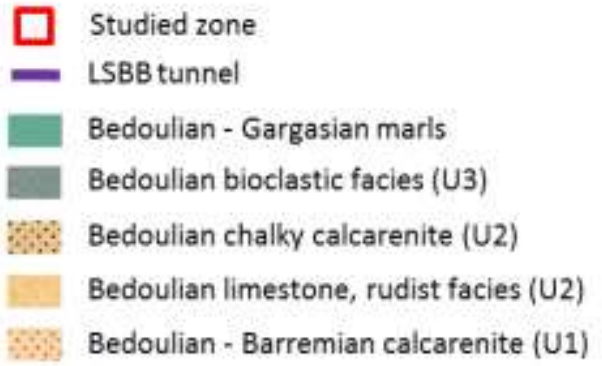

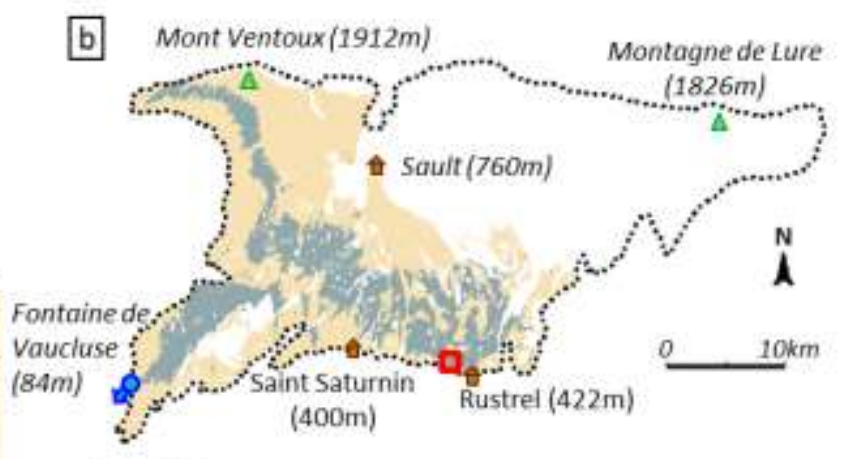

\section{Legend:}

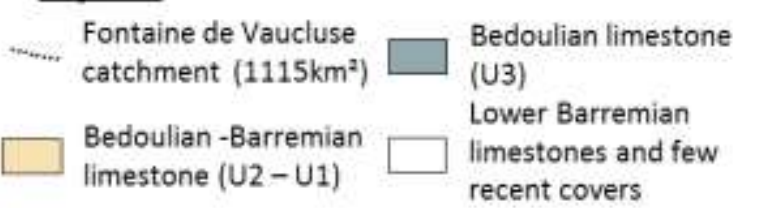

d]

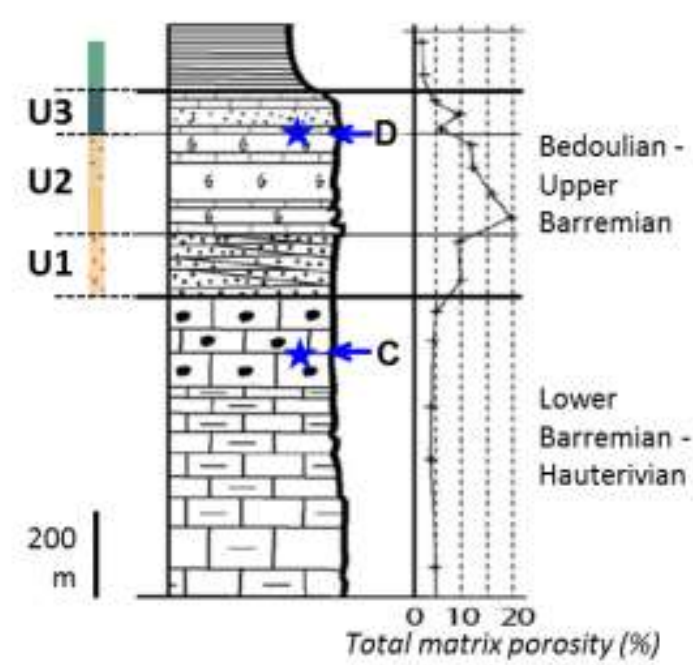

Fig. 2: (a) The Fontaine de Vaucluse basin located in France; (b) The Rustrel experimental site located in the Fontaine de Vaucluse basin; (c) Excerpt of local geological map, $n^{\circ} 942$ (after Blanc et al. 1973);

(d) Total porosity of limestone outcropping on Fontaine de Vaucluse hydrosystem measured in a small sample (after Guglielmi 2010).

\subsection{Local geological structure investigated in previous studies}

The geological structure of the study site was investigated using geophysical and geological surveys

127 (Carrière et al. 2013) and geological modeling (Ollivier et al. 2013). To detect geological structure, a

128 combination of ground penetrating radar (GPR) and electrical resistivity tomography (ERT) were used

129 to identify geological features that may impact groundwater dynamics. The GPR results provide near surface high-resolution imaging and thus can provide relevant geological information such as stratification and fractures (Fig. $3 b$ and c). Despite the exceptional quality of the results, GPR's 
132 investigational depth remains limited to around $12 \mathrm{~m}$. ERT is able to investigate down to $40 \mathrm{~m}$, but it

133 is an integrative technique that has lower resolution than GPR. In the study area, the investigated

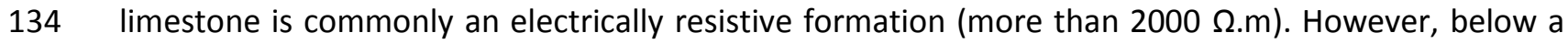

135 depth of 5-7 m, the ERT profiles reveal several zones of moderate resistivity (around $900 \Omega . m$ ). In

136 these zones, cross-stratifications were clearly identified by GPR. The combination of both GPR and

137 ERT results, in addition to field geological studies and geotechnical observations (recorded during

138 underground passageway construction), lead to a well-founded geological interpretation (Fig. 3).

139 Cross-stratifications formed under certain sedimentation conditions (high energy, for example) may

140 have produced a more porous limestone. However, during the first phase of the study, it was

141 impossible to determine the exact role of the identified geological features. What are the respective

142 roles of the detected faults, fractures, or crushed zones? Is it possible to monitor water recharge

143 dynamics in the moderate resistivity zone? These questions were answered during the second phase

144 of the study presented in this paper.

145 Ollivier et al. (2013) performed geological modeling (Fig. 3b) using GOCAD software to combine all 146 available geophysical, geological, and geotechnical information. This geological modeling made it 147 possible to propose a well-founded interpretation for geological structures and to extend the analysis 148 of the site below the depth investigated by geophysics. 


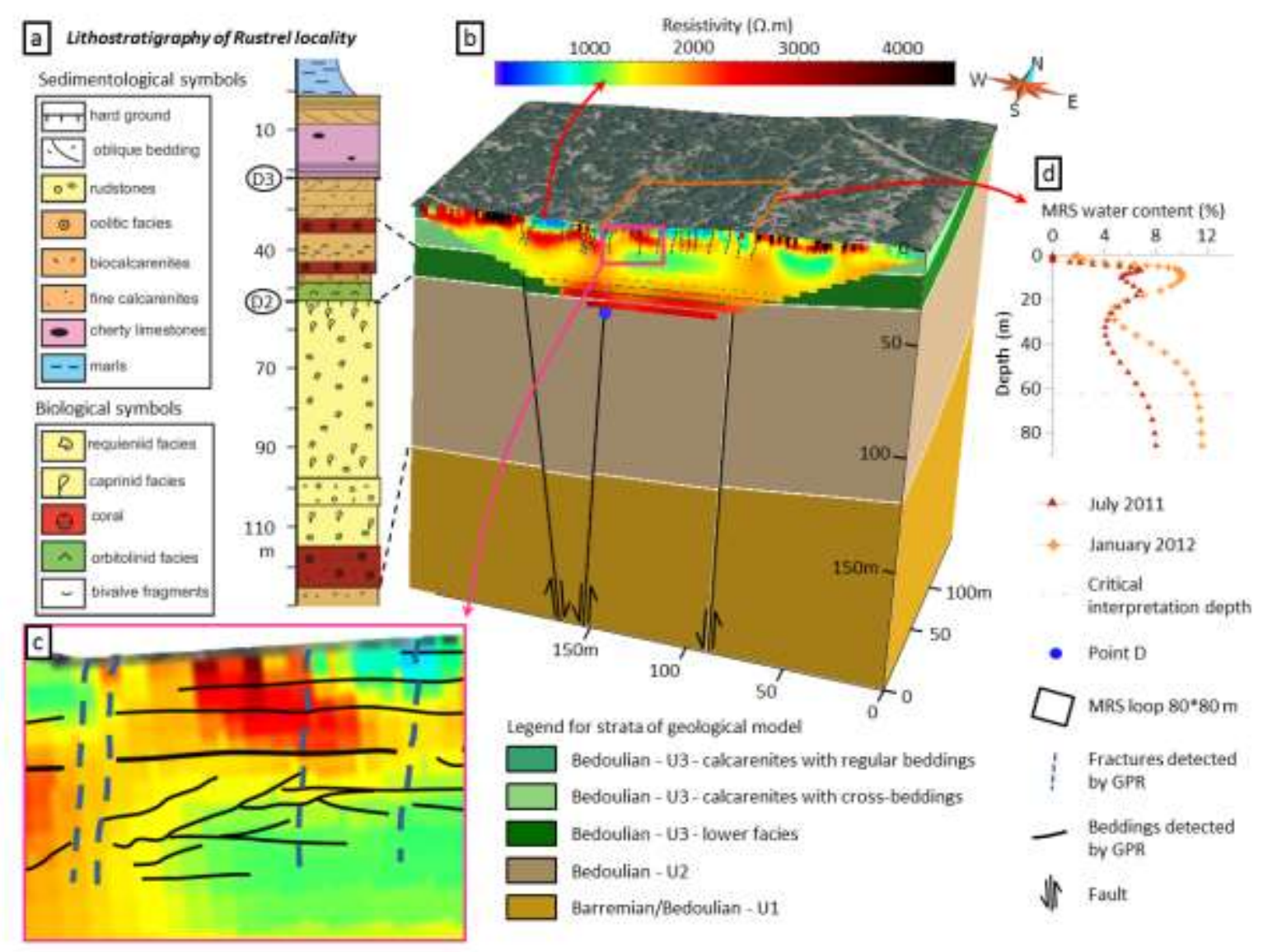

Fig. 3: Comparison between different types of geological and geophysical information: (a) Regional lithostratigraphic log (Masse and Fenerci-Masse 2011 (modified)); (b) 3D geological model (Ollivier et al. 2013) with $252 \mathrm{~m}$ long electrical resistivity tomography (ERT) section LSBB03, inverted in three iterations; (c) Zoom on ERT section LSBB03 with bedding and fractures detected by ground penetrating radar (GPR); (d) Magnetic resonance soundings (MRS) of July 2011 and January 2012

(Carrière, 2014).

\section{An integrated hydrogeophysical approach: methods and tools}

The approach used in this study combines several tools (surface based geophysics, geology and tectonics, geotechnical information, hydrodynamics, and infiltration modeling) to explain the functioning of the local hydrosystem.

\subsection{Effective infiltration assessment}

163 To assess as accurately as possible the effective infiltration entering locally into the karst hydrosystem, exchanges between soil/plant/atmosphere were modeled using CASTANEA (Davi et al. 
2005; Dufrêne et al. 2005). This model calculates the effective infiltration by taking into account the following processes: canopy water interception, tree transpiration, soil and litter evaporation, dynamics of soil water content and drainage. This model is based on the Penmann-Monteith equation for calculating evapo-transpiration. The model includes the downregulation of soil drought on transpiration via stomata closure. CASTANEA is a species-specific model that considers features of the forest environment in the study area. CASTANEA was validated in a similar environment (Mediterranean shrubby forest with holm oak) at the Puéchabon site (southern France) using eddycovariance measurements (Davi et al. 2006; Martin 2012). A requisite inventory of forest species was conducted for a representative zone measuring $120 \mathrm{~m}$ by $20 \mathrm{~m}$ to define stand-specific input parameters; it included a tree inventory to assess the standing biomass, hemispherical photographs to assess the canopy Leaf Area Index (Davi et al. 2008), and soil pits to estimate soil water content.

Meteorological data were recorded at the Centre d'Information Régional Agro-Météorologique et Economique (CIRAME) station at Saint Saturnin-les-Apt (Fig. 2). Between 2004 and 2012, average daily temperatures ranged between -7.2 and $28.7^{\circ} \mathrm{C}$. The average annual temperature was $13.5^{\circ} \mathrm{C}$ and the average annual rainfall was $660 \mathrm{~mm}$.

\subsection{Flow measurement}

The discharge rate at point $D$ has been monitored since 2003 to study the response of the UZ to natural rainfall events (Garry 2007; Blondel 2008; Barbel-Perineau 2013). Flow point D shows smooth hydrodynamic behavior even though it is located at a depth of $33 \mathrm{~m}$ (Fig. 4 and 5).

Within the LSBB passageway, 42 other flow points have also been monitored since 2003. In this paper, we compare point $D$ to point $C$; these two points show the maximum difference in terms of hydrodynamics. The measurement frequency was almost weekly (349 measurement campaigns at the end of 2012). Discharges are measured by collecting water in a graduated cylinder over a period of time. 


\subsection{Geophysics implementation, acquisition strategy, and field constraints}

191 After extensive testing with a large array of geophysical methods (electromagnetic, electric, 192 gravimetric, and nuclear magnetic resonance), (Carrière, 2014), two efficient and accurate 193 techniques were selected to study hydrodynamics at the local scale (few hundred meter squares): 194 ERT and magnetic resonance sounding (MRS). These geophysical techniques make it possible to image temporal variation in complementary physical properties of the subsurface (until $90 \mathrm{~m}$ ). This variation may be related to variation in water content and thus may shed light on hydrodynamic behavior.

Measurements at the study site were conducted at two time scales: (i) with a seasonal time step to flows. preparation prior to measurements. The exact position of all geophysical measurements was measured with the real time kinematic (RTK) acquisition method every $2 \mathrm{~m}$ using the differential global positioning system (GPS) TRIMBLE 5800.

\section{$\underline{3.3 .1 M R S}$}

207 MRS is the only ground-based geophysical method that can obtain a signal directly related to the presence of water to a depth of several meters. MRS, which is designed for a quantitative description of aquifer formations, is based on the phenomenon of hydrogen proton magnetic resonance. The MRS array generates a signal with a specific frequency to excite the hydrogen protons in water molecules, and the MRS signal received is specifically related to groundwater (e.g. Legchenko et al. 2002; Vouillamoz et al. 2003). 


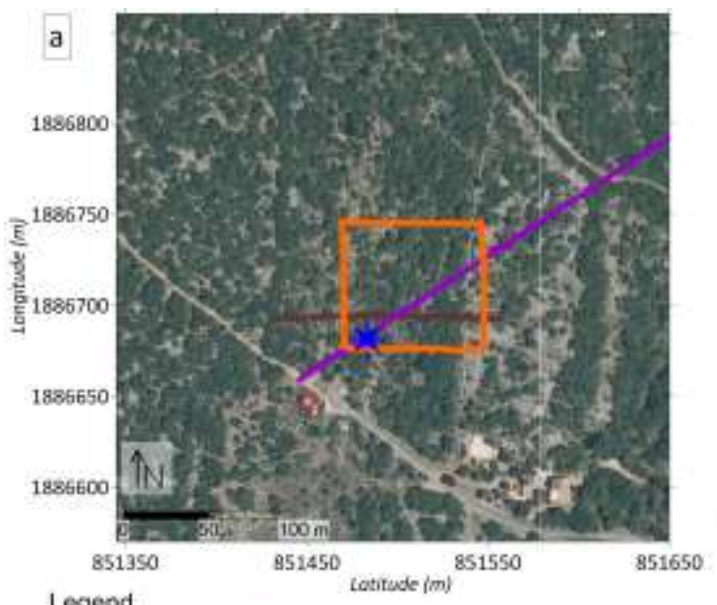

Legend

- LSB8 tunnel

- Lse8 tunnel

Emergency exit of LSBB

- MRS loop

- ent survey

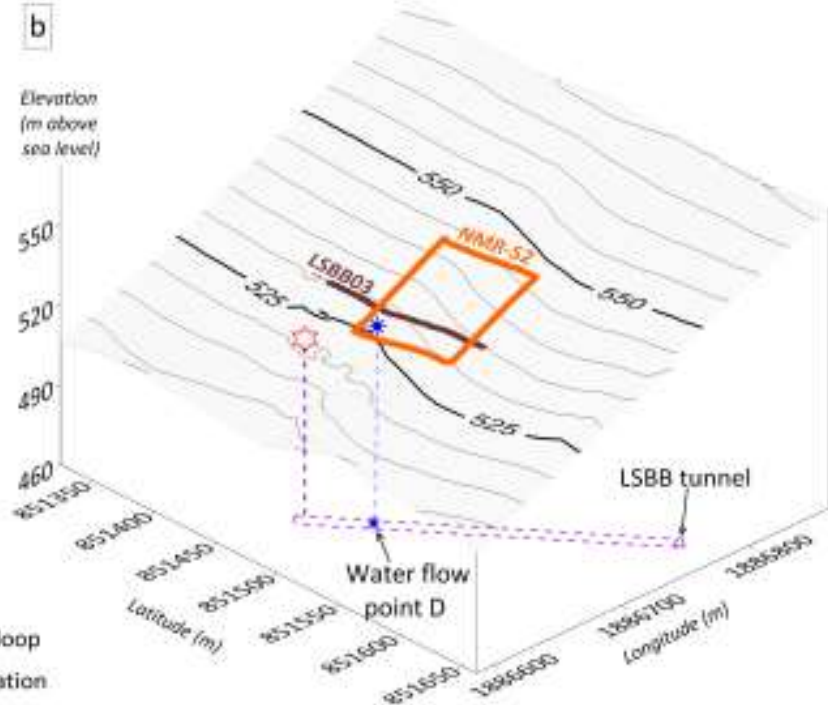

Fig. 4: Experimental site of the Low Noise Underground Laboratory (LSBB): (a) location of geophysical measurements on aerial photo; (b) pseudo 3D location of geophysical measurements discussed in this paper.

The minimal amount of time necessary to conduct an MRS survey (approximately one day per sounding) and the high cost of the equipment led to the use of this geophysical technique at the seasonal time step for imaging seasonal variations in water content. Only two MRS surveys were repeated at the seasonal time step and the results of both show the same dynamics. In this paper, the temporal variability of only one MRS sounding, MRS S2, is presented and discussed. This sounding was chosen because it is located above the moderate resistivity zone detected with ERT.

The acquisition system used is a Numis Plus by IRIS instruments. The measurements were collected in summer (July 2011) and in winter (January 2012). To integrate a large area above water point D, a wide MRS array $(80 \times 80 \mathrm{~m})$ was chosen for these surveys. It is important to mention that for both MRS surveys, electromagnetic noise was low compared to signal amplitude (ratio signal to noise $>1.5$ ) which ensure interpretability and comparability between measurements (e.g. Legchenko et al., 2002). The details of MRS results from this site were discussed and presented by Mazzilli et al. (2012) and Chalikakis et al. (2014). These results indicated the presence of a significant amount of water in the UZ karst to a depth of $90 \mathrm{~m}$ (MRS sometimes indicated a water content greater than $10 \%$ ). Eight MRS were conducted at the experimental site to study the spatial variability of MRS signals. All 
soundings exhibit similar forms. However, significant lateral variation in water content was observed between soundings (Mazzilli et al. 2012), revealing that the karst UZ is also a heterogeneous environment in terms of water content.

\section{$\underline{3.3 .2 E R T}$}

The ERT technique has been widely used in karst areas because it is robust and reliable (e.g. Cardarelli et al. 2006; Robert et al. 2012). The sensitivity of electrical resistivity to moisture variations and the rapidity of ERT measurements (approximately one hour per section) led to the selection of this geophysical technique to image rapid resistivity variation during heavy rainfall. During the 30 day campaign, ERT time-lapse acquisition ranged from every three hours during the rain event (17 days) to one section a day after the rain event.

The acquisition system used is an ABEM Terrameter SAS 4000 (Dahlin 2001) with four channels and 64 electrodes. Implantation of the ERT electrodes, mainly at limestone outcrops, required holes that were mechanically dug into the rock; saltwater and mud were added to ensure a good quality ground contact. The ERT section LSBB03 acquired with Gradient array is presented in this paper (Fig. 4). The section is oriented east-west. This direction is perpendicular to the general slope, is subperpendicular to one of the main fault and lineament directions, and is the most heterogeneous direction in terms of apparent resistivity spatial distribution (Carrière et al. 2013). The Gradient array was chosen for this survey because of its robustness and its rapidity (Dahlin and Zhou 2004).

A portion of the first ERT results were presented by Carrière et al. (2015) to evaluate the effectiveness and technical limits of ERT to monitor water infiltration via previously recognized karst features under natural conditions.

Apparent (directly measured) resistivity $\left(\rho_{\alpha}\right)$ analysis is not usually considered in ERT surveys. However, Carrière et al. (2015) demonstrate that with the current technology, in this kind of complicated media, existing inversion schemes are not adequate. It was hoped that raw results with no artifacts related to inversion schemes could provide relevant information. If one analyzes 
variation in resistivity of inverted sections, it is only possible to observe general evolution of the near surface. Due to its integrative character, the inversion process smooths any fine variation even if one tries to observe only inverted resistivity variation between two consecutive time steps. In this context, apparent resistivity variations $\left(\Delta \rho_{\alpha}\right)$ between two consecutive time steps were analyzed. These variations were normalized by the delay $\left(\Delta_{T}\right)$ between consecutive measurements $\left(\rho_{n}\right.$ and $\left.\rho_{n-1}\right)$ using the following equation (Eq.1).

$$
\Delta \rho_{\alpha}=\left(\frac{\rho_{n-1}}{\rho_{n}}-1\right) \frac{100}{\Delta_{T}}
$$

\section{Results and interpretation}

The hydrodynamics of flow points $C$ and $D$ as a function of recharge (rain and effective infiltration) is presented first, followed by the results of geophysical monitoring at both seasonal and event time scales.

\subsection{Flow dynamics versus rain and effective infiltration}

Two hydrological periods can be observed: a dry period from 2004 to 2007 and a rainy period from 2008 to 2013 (Fig. 5) (Barbel-Perineau et al. 2013). Effective infiltration modeling using CASTANEA

(Fig. 5) confirms this alternation of wet and dry periods. One notes that effective infiltration is quite limited between 2004 and 2007. Rigorous modeling of effective infiltration is essential in supporting subsequent interpretations because the difference between rain and effective infiltration can be quite large and can lead to misinterpretation.

During the first dry period, the water discharge at point $D$ generally decreases and there is no clear reaction during rain events. On the contrary, during the second rainy period, this water discharge increases and responses to rain events are more apparent. The regularity of point $D$ is obvious when comparing variation ranges between points $D$ and $C$.

Point $C$ discharge is highly reactive to rainfall; it shows typical karstic dynamics even though it is located at a depth of $256 \mathrm{~m}$ (Fig. 5). Note that the reactivity of flow point $D$ to a rain event differs 
from dry period (no variation) to wet period (rapid discharge increases for strong rainy events).

However, the flow rate at point $\mathrm{C}$ increases proportionally with effective infiltration in both dry and wet periods. Without more arguments, it is difficult to explain the difference between D and C. One can only point out that point $D$ is located within porous Urgonian limestone and $C$ is located within lower Barremian limestone (Fig. 2d).

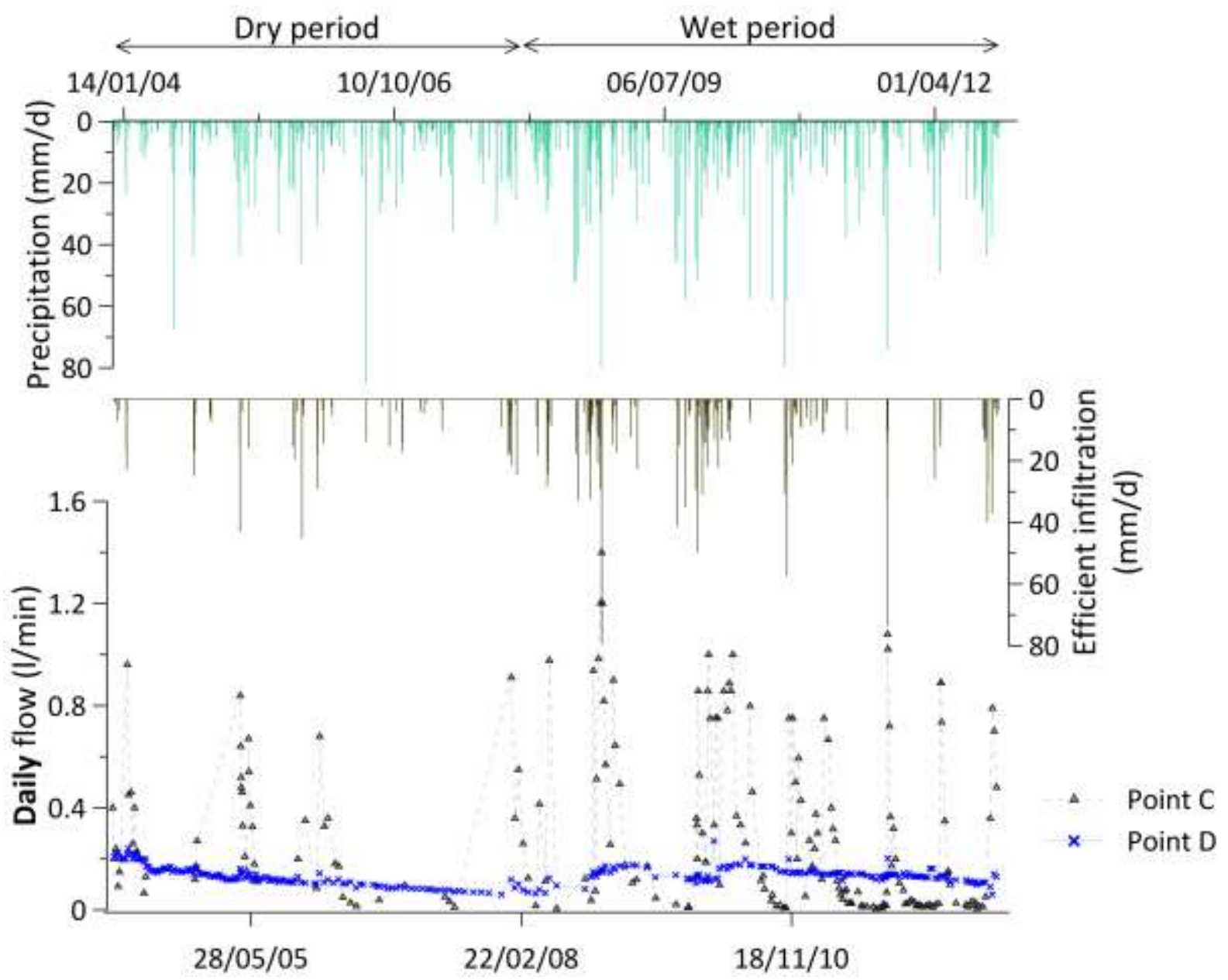

Fig. 5: Precipitation and effective infiltration calculated using CASTANEA compared with flow dynamics at points C and D between 2004 and 2012.

\subsection{Hydrogeophysical monitoring}

\subsubsection{Seasonal dynamics}

MRS was used to detect the seasonal variation in storage in the karst UZ between summer 2011 and winter 2012. In processed MRS results (Fig. 3d), two layers reveal unusual water contents for karst UZ. The first interval with high water content ( $10 \%$ water content according to MRS) is at a depth of 
approximately $15 \mathrm{~m}$ (above low point D); the other high water content interval (12\% water content

299 according to MRS) is deeper than $40 \mathrm{~m}$.

300

301

302

303

304

305

306

307

308

309

310

Although these elevated water contents are surprising for a karst hydrosystem UZ, these values agree with the high porosity estimated by other geophysical methods used at the LSBB (Maufroy 2010; Bereš 2013) and total matrix porosity measured in plugs in the region (e.g. Masse 1969; Léonide et al. 2014) (Fig. 2d).

Significant temporal variations in MRS water content are observed at several depth levels (Fig. 3d). The measured variations are as high as $3 \%$ water content. This result indicates that these storage variations could participate in seasonal water flow regulation in the karst UZ.

It is difficult to conceive that such a large volume of water could be stored in fracture and conduits porosity of karst UZ. For this reason, in this geological context where limestone can be very porous, the majority of this water content can be attributed to the porous matrix.

The high water content level detected by MRS near the depth of $15 \mathrm{~m}$ corresponds to location of the cross-stratifications and a moderate resistivity zone detected by GPR and ERT (Fig. 3b and c). This feature probably contains a stock of water located above point $D$, and supplies this water to point $D$. Its hydrogeological role will be discussed in the next section.

\subsubsection{Event dynamics}

This unique large-scale ERT surface based experiment was conducted during a typical Mediterranean autumn rain event (17 days). A total of $230 \mathrm{~mm}$ of rain were recorded and 120 ERT time-lapse sections were measured over the same profile (LSBB03) during and after the rain event (a total of 30 days).

Apparent resistivity values have been arithmetically averaged for each section. Apparent resistivity decreased sharply during the rain event, from 1750 to $1050 \Omega$.m (Fig. 6b). These variations do not seem to be related to temperature variations because air temperature and water temperature (at 
point D) remained stable during the experiment (Carrière 2014). Thus, these electrical resistivity variations can be reasonably related to variation in water content in the subsurface. Analysis of this mean apparent resistivity indicator made it possible to select the twelve critical time steps presented in Fig. 6a: before, during, and after the rain event. These results are presented (Fig. 6a) as hourly percentage changes in $\rho_{\alpha}$ with a basic representation of vegetation and soil cover around the profile. Previously recognized karst features (Carrière et al. 2013) are also represented.

At the beginning of the rain event (Fig. 6a, section $1 \rightarrow 2$ ), $\rho_{\alpha}$ decreased moderately and homogeneously along the section. This resistivity decrease could be related to moistening of near surface horizons. After the first rain event (Fig. 6a, section $2 \rightarrow 3$ ), $\rho_{\alpha}$ stabilized quickly. During the following heavy rain episode (Fig. 6 a, sections $4 \rightarrow 5$ to $7 \rightarrow 8$ ), the moistening process appeared to be quite heterogeneous and some zones resembled water pathways or preferential infiltration zones. However, it would be unwise to link observed $\rho_{\alpha}$ variations at depth with deep moistening processes. The observed variations can also be directly influenced by near surface variations. Immediately after the rain (Fig. 6a, sections $9 \rightarrow 10$ and $10 \rightarrow 11$ ), $\rho_{\alpha}$ increased in some zones. This result may be related to drainage processes. These zones correlate well with zones previously identified as preferential pathways. This second observation reinforced the hypothesis of preferential pathways playing a hydraulic role that can be traced with ERT monitoring. However, it is still not possible to specify properties such as the geometry of these pathways. Other zones where such drainage processes are not identifiable may be related to zones where soil is thicker and remains moist after rainfall.

The assumed water pathways identified on the basis of apparent resistivity do not seem to be related to vegetation density or soil cover variations (Fig. 6). However, these zones appear related to fractures or fault zones previously detected by GPR (Carrière et al. 2013). Note also that resistivity variations in fractures are different from those measured in the crushed zone located in the western part of the profile. A crushed zone may provide a larger water pathway than a fracture. It is 347 important to emphasize that the methods used in this study do not image the pathways with certainty. 


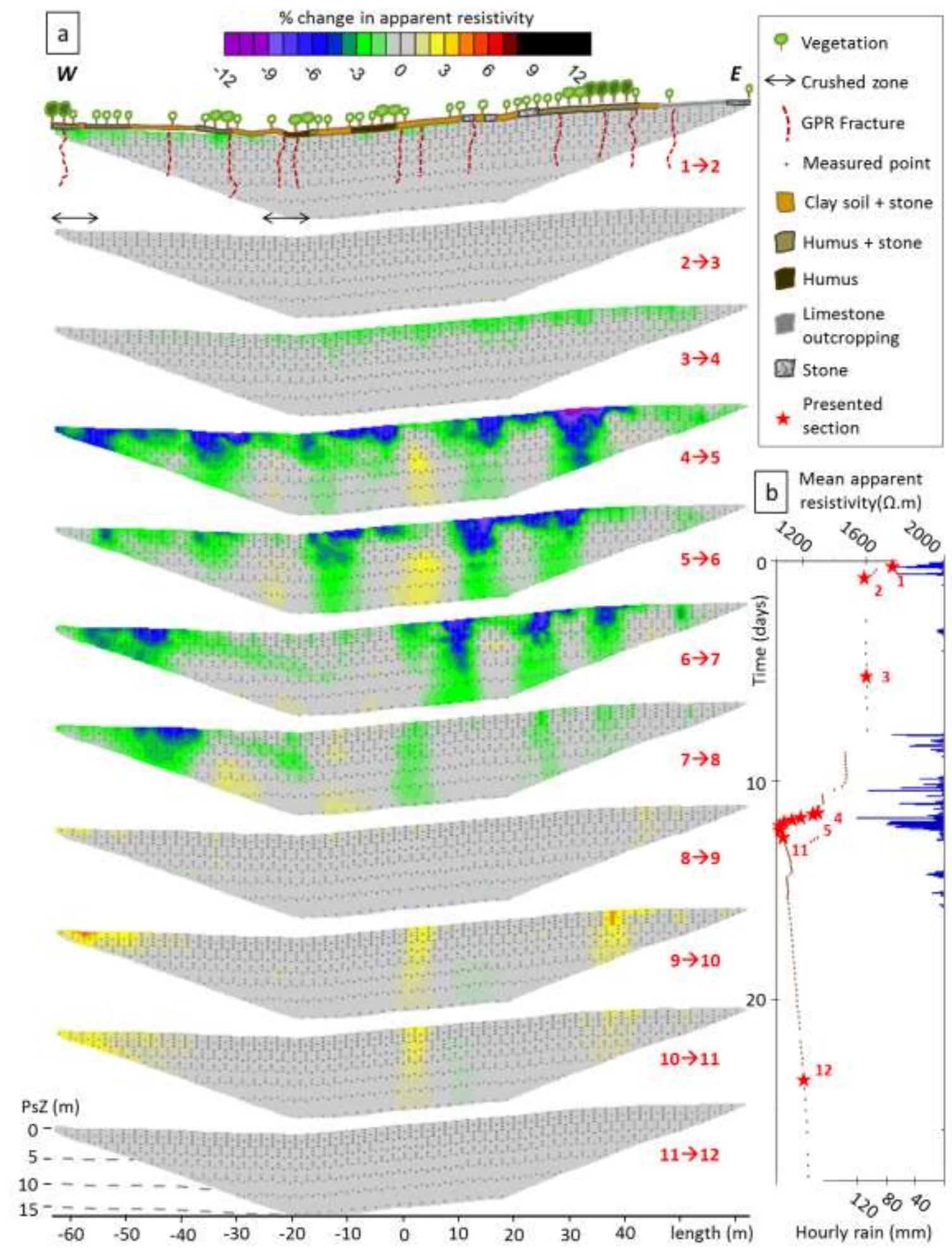

Fig. 6: (a) Hourly change in apparent resistivity between two consecutive time steps. Positions of fractures previously detected by ground penetrating radar (GPR) and basic representation of vegetation and soil cover; (b) Evolution of mean apparent resistivity during monitoring versus rain. Each brown point represents one electrical resistivity tomography section (Carrière et al. 2015). PsZ is pseudo depth. 


\section{Discussion}

357

\subsection{Local scale: study area}

This integrated hydrogeophysical approach at two different time scales has improved the current understanding knowledge of the hydrogeological functioning of study site. At the seasonal time step, MRS made it possible to identify water storage variation above and below flow point $D$. These variations are related to slow water dynamics within matrix porosity. This hypothesis is consistent with the regular flow dynamics at point $D$, which were observed during both dry and recharge periods (Fig. 5). Moreover, it is consistent with the large total matrix porosity within Urgonian limestone, which may reach $20 \%$ (Fig. 2d).

At the rain event time scale, ERT monitoring revealed heterogeneity in infiltration (Fig. 6). Some fractures or faulted zones previously detected by GPR (Fig. 3) were identified as probable preferential water pathways (Fig. 7b and d).

During wet periods, when water fills these vertical structures, hydraulic head $(\Delta h)$ increases above flow point $D$, which induces a prompt increase in flow at $D$ as in October 2011 (Fig. 7d) during ERT monitoring (Fig. 6). During this type of rain event, this increased flow may push forward older, less mobile water according to the water schema proposed by Barbel-Perineau (2013) who studied hydrochemistry within the LSBB.

During long dry periods, as for example, between 2004 and 2007 (Fig. 7a), flow point D did not respond to rain pulses even during extreme events (Fig. 7b). Thus, there is probably no significant hydraulic continuity between near-surface water-filled fractures and the deeper porous matrix reservoir. Thus, there is no transmission of a pressure pulse to cause increased flow at point $\mathrm{D}$. This absence of connection is probably due to partial drying of the porous matrix reservoir above point $D$. The evolution of the dry porous matrix to water-filled matrix may take several years. This timeframe can explain the multi-annual inertia to recharge the stock that supplies point $D$, as was observed between 2007 and 2010 (Fig. 5). 
385

386

387

388

389

390

391

392

393

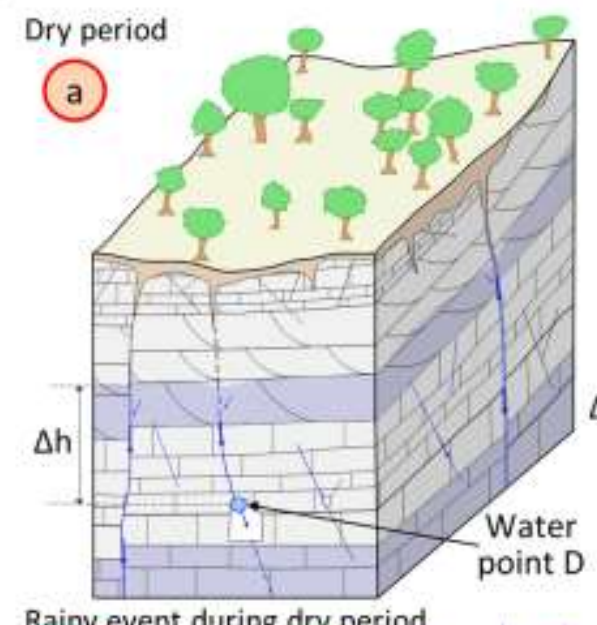

Rainy event during dry period

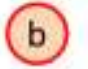

(b)

$\Delta \mathrm{h}$
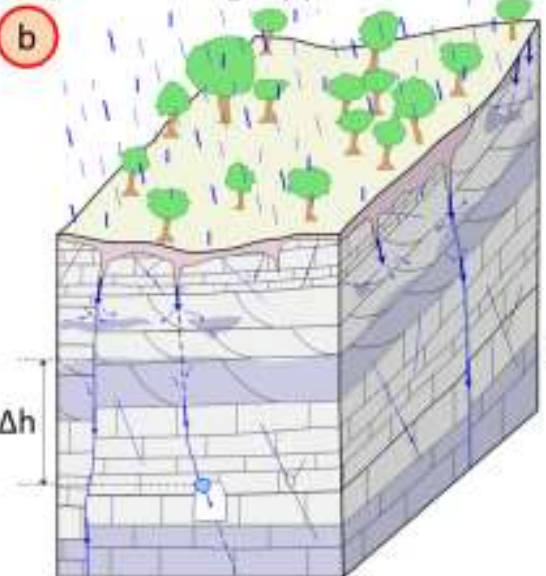

$\Delta \mathrm{h}$

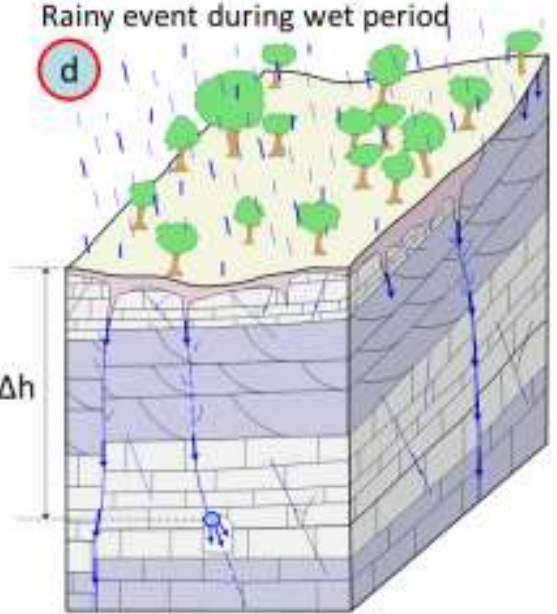

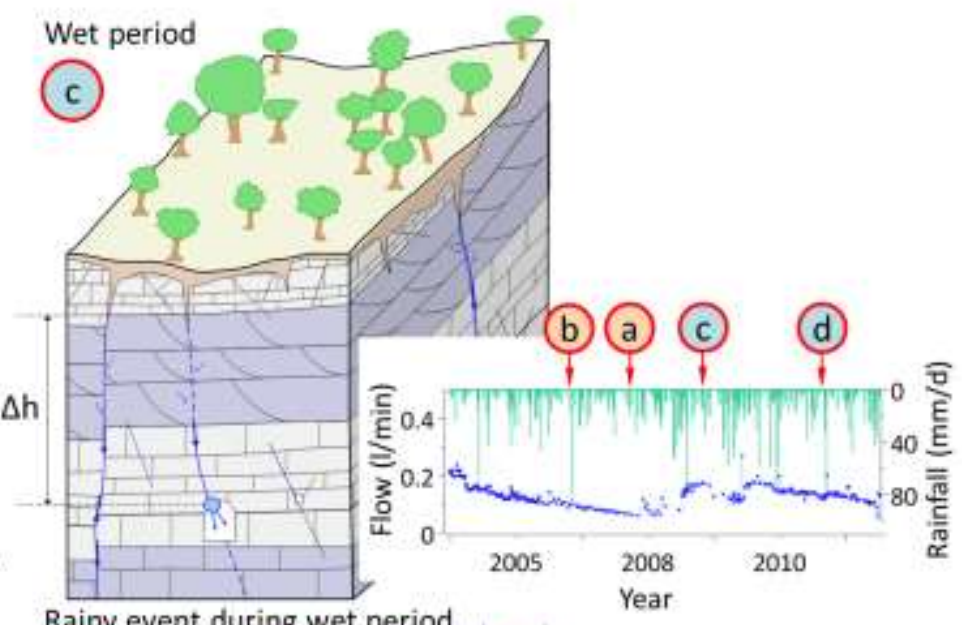

Legend

$\square$ Wet soil

Dry soil

Limestone with

high water content

Limestone with

low water content

Fig. 7a-d: Synthetic functioning model of the local hydrosystem that supplies flow point D. D flow variation depends on rain conditions.

\section{$\underline{5.2 \text { Regional scale: Fontaine de Vaucluse hydrosystem }}$}

How can this knowledge about the local hydrosystem at point $D$ help explain karst hydrodynamics at a larger scale, such as the entire Fontaine de Vaucluse hydrosystem?

It is particularly relevant to study the relationship between rainfall and water discharge during the period from 2004 to 2012 because recharge was highly variable during this period. A long dry period between 2004 and 2007 was followed by a more rainy period between 2008 and 2012. The annual 
dynamics of rainfall, effective infiltration, and water discharge presented in Fig. 8 illustrate these dry and wet periods.

Although these results are applicable to a discussion of the relationship between rainfall and output flow at LSBB flow points, the relationship with spring discharge at the Fontaine de Vaucluse should be approached with caution. However, the total annual rainfall in Saint Saturnin-les-Apt (Fig. 2b) is representative enough of inter-annual rainfall variation in the region to allow the following discussion.

These inter-annual recharge variations cause changes in discharge rates at the outlet of the karst system as a whole (Fontaine de Vaucluse spring) and at local outlets of karst sub-systems such as water points $C$ and $D$ in the LSBB. However, these variations are highly variable between the Fontaine de Vaucluse and water points $C$ and $D$, and are summarized as follows:

- Water point $C$ exhibits typical karst dynamics with large flow range (a factor of 10 ) depending on the quantity of annual effective infiltration. This relationship was clearly demonstrated in 2007 when effective infiltration was at a minimum and water flow at $C$ was very low.

- The water point $D$ has different dynamics because its water discharge is quite regular; the range of its annual discharge variation is only a factor of 2 . The flow rate at point $D$ decreased continuously between 2004 and 2007, after which its flow increased regularly until 2010. However, effective infiltration decreased significantly between 2008 and 2010. Thus, there is a kind of delayed dynamic. The results highlight the importance of porous matrix on water flow, even in a karst limestone aquifer system.

- The annual water discharge of the Fontaine de Vaucluse exhibits dynamics similar to those at point $D$ (Fig. 8) although its flow variation range is slightly larger than point $D$, a factor of 3.5 . Similar to point $D$, the flow rate at the Fontaine de Vaucluse also increased between 2007 and 2010; however effective infiltration decreased significantly from 2008 to 2010. This observation suggests that water flow regulation mechanisms observed at point $D$ are site-specific. Similar mechanisms of water flow regulation through the porous matrix may play an important role in the entire Fontaine 
421 de Vaucluse hydrosystem (Fig. 8). Considering the large volume of Urgonian porous formations in the

422 hydrosystem (Fig. 2b), this assumption is a plausible explanation of part of the multi-annual dynamics 423 of the Fontaine de Vaucluse spring.

424 Even so, at a daily time step, the Fontaine de Vaucluse spring can be highly reactive, similar to flow point C. However, even if floods at the Fontaine de Vaucluse can be impressive, they represent only a limited part of the annual water discharge. The annual flow dynamics of the Fontaine de Vaucluse point D.

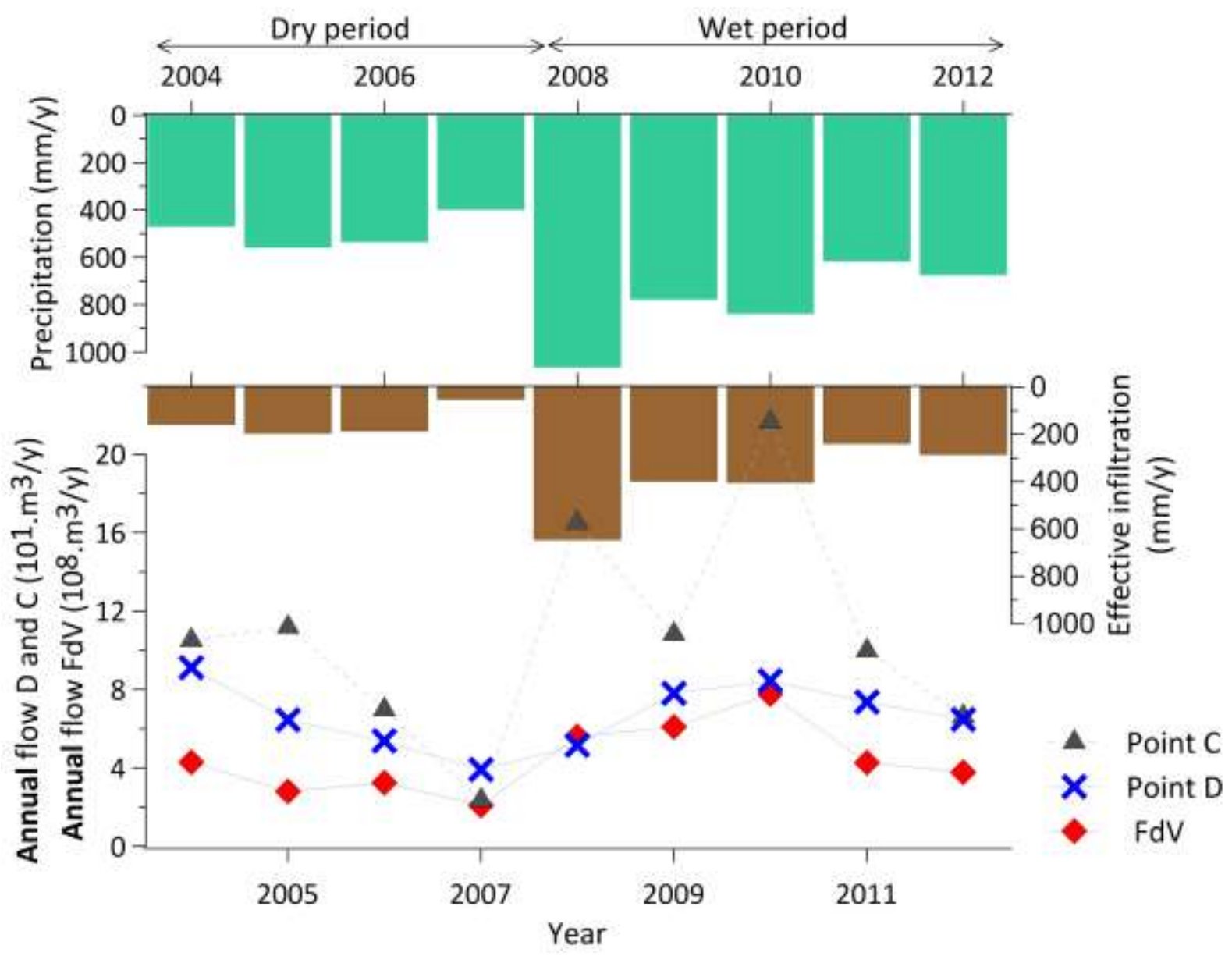

Fig. 8: Comparison of annual water discharge for Fontaine de Vaucluse (FdV) and flow points $D$ and $C$ with annual precipitation and effective infiltration modeled for the period of 2004 to 2012 by 
This study was conducted at a local scale around the LSBB underground laboratory to improve the

437 current understanding of the local karst hydrosystem. The results presented in this paper 438 demonstrate that a considerable volume of water can be stored within matrix rock in the karst UZ. Masse (1969) measured exceptional matrix porosity for limestone (up to $20 \%$ ) on the Urgonian platform around Fontaine de Vaucluse catchment area. However, the hydrodynamic role of this matrix porosity was not yet known.

442 MRS surveys confirmed high free water content (5 to $10 \%$ ) within the karst UZ. This high water 443 content indicates a large volume of water that cannot be stored within fractures or karst conduits in 444 the UZ. This water is stored within limestone layers that were also identified by previous ERT and GPR surveys. Moreover, MRS surveys identified seasonal variations in stored water (around $3 \%$ ), which indicates that this water reserve is active. The ERT monitoring at the event scale made it possible to demonstrate that despite the presence of porous limestone, the study site has characteristics of a fractured/karstified area in which recharge processes are highly heterogeneous. Rapid water circulation can occur through preferential water pathways and cause flow peaks at point D.

451 Without additional measurements, the geophysical survey cannot be used to extend the hydrodynamic properties observed at the LSBB site to the Fontaine de Vaucluse hydrosystem, either wholly or in part. That is why it is not reasonable to try to quantify the consequences of the presence of porous limestone on the Fontaine de Vaucluse spring flows. However, considering that Urgonian limestone covers more than half the surface area of the Fontaine de Vaucluse basin (Fig. 2b) and that Masse (1969) measured high matrix porosity on the entire Urgonian platform, there are necessarily repercussions in Fontaine de Vaucluse outlet flow that may explain the multi-annual dynamics of water flow (Fig. 8).

If Urgonian limestones play an important role in Fontaine de Vaucluse hydrodynamics, similar geological formations can similarly impact the hydrodynamics of other karst hydrosystems, including areas far from the Mediterranean Sea where the sedimentary conditions are similar. For example, 
463 Schmoker, 1983). Therefore, on the basis of these results presented, it is essential to consider the

464 role of the porous matrix in water flow regulation within a karst UZ. Hydrodynamic modelling should be adjusted accordingly to assess properly the groundwater resource potential and improve sustainable management and exploitation of karst hydrosystems.

\section{Acknowledgments}

The authors would like to express their gratitude to CIRAME, to ORE $\mathrm{H}+$ and to all the LSBB team for their technical and logistic help. This study was funded by a French ministry of education and research PhD grant. This work was performed within the framework of the FDV/LSBB observation site, part of the KARST observatory network (www.sokarst.org) initiative of INSU/CNRS, which seeks to support knowledge sharing and promote cross-disciplinary research on karst systems. We also thank the editorial board of Hydrogeology Journal, S. White, M. Saribudak and an anonymous reviewer for helping us improve this paper.

\section{References}

Aquilina L, Ladouche B, Dörfliger N (2006) Water storage and transfer in the epikarst of karstic systems during high flow periods, J. of Hydrology 327(3-4): 472-485.

Bailly-Comte V, Martin JB, Jourde H, Screaton EJ, Pistre S, Langston A (2010) Water exchange and pressure transfer between conduits and matrix and their influence on hydrodynamics of two karst aquifers with sinking streams. J. of Hydrology 386 (1-4): 55-66. doi: 10.1016/j.jhydrol.2010.03.005.

Bakalowicz M (1995) La zone d'infiltration des aquifères karstiques: méthodes d'étude, structure et fonctionnement [Infiltration zones in karst aquifers: methods of study - structure and functioning]. Hydrogéologie (4), 3-21.

Bakalowicz M (2005) Karst groundwater: a challenge for new resources. Hydrogeology J. 13: 148-160.

Bakalowicz M, Dörfliger N (2005) Ressources en eau du karst : un enjeu pour le bassin méditerranéen. [Karst water resources: an issue for the Mediterranean basin] Géosciences - l'eau souterraines BRGM 2, 26-31.

Barbel-Perineau A (2013) Caractérisation du fonctionnement de la zone non saturée des aquifères karstiques - Approche directe par études hydrodynamiques et hydrochimiques sur le bassin de recherche, d'expérimentation et d'observation de fontaine de Vaucluse - Laboratoire Souterrain à Bas Bruit de Rustrel - Pays d'Apt. [Characterization of behavior of the unsaturated zone of karst aquifers - Direct approach through hydrodynamic and hydrochemical studies on the research, 
experimental and observational basin of the Fontaine de Vaucluse-Underground Low Noise Laboratory of Rustrel - Pays d'Apt] Thesis: Univ. d'Avignon et des Pays de Vaucluse, 226 p.

Batiot C, Emblanch C, Blavoux B (2003) Total Organic Carbon (TOC) and magnesium (Mg2+): two complementary tracers of residence time in karstic systems. C. R. Geosci. 335(2): 205-214.

Bereš J (2013) Caractérisation de l'anisotropie d'une plate-forme carbonatée karstifiée: approche méthodologique conjointe sismique et électrique. [Characterization of anisotropy of a karstified carbonate platform: joint seismic and electric methodological approach] Thesis: Univ. Paris Sud, Orsay, $190 \mathrm{p}$.

Berkowitz B (2002) Characterizing flow and transport in fractured geological media: A review. Advances in Water Resources 25(8-12): 861-884.

Blanc MM, Masse JP, De Peyronnet $P$, Roux M, Weydert P, Rouire J (1973) Carte géologique et notice explicative (1/50 000), feuille 942, [Geologic Map and Explanatory Notes $(1 / 50,000)$ Sheet 942 ] Saultde-Vaucluse, France. BRGM, Orléan.

Blondel T (2008) Traçage spatial et temporel des eaux souterraines dans les hydrosystèmes karstiques par les matières organiques dissoutes. Expérimentation et application sur les sites du Laboratoire Souterrain à Bas Bruit (LSBB) de Rustrel - Pays d'Apt et de Fontaine de Vaucluse. [Spatial and temporal tracing of groundwater in karst hydrosystems using dissolved organic matter. Experiments in and application to sites within the Underground Low Noise Laboratory (LSBB) of Rustrel - Pays dApt and the Fountaine de Vaucluse] Thesis: Univ. d'Avignon et des Pays de Vaucluse, $192 \mathrm{p}$.

Cardarelli E, Di Filippo G, Tuccinardi E (2006) Electrical resistivity tomography to detect buried cavities in Rome: a case study. Near Surface Geophysics 4(6): 387-392.

Carrière SD, Chalikakis K, Sénéchal G, Danquigny C, Emblanch C (2013) Combining Electrical Resistivity Tomography and Ground Penetrating Radar to study geological structuring of karst Unsaturated Zone. J. of Applied Geophysics 94(0): 31-41. doi : 10.1016/j.jappgeo.2013.03.014.

Carrière SD (2014) Etude hydrogéophysique de la structure et du fonctionnement de la zone non saturée du karst. [Hydrogeophysical study of the structure and functioning of the karst unsaturated zone] Thesis: Univ. d'Avignon et des Pays de Vaucluse, 217p.

Carrière SD, Chalikakis K, Danquigny C, Clément R, Emblanch C (2015) Feasibility and Limits of Electrical Resistivity Tomography to Monitor Water Infiltration Through Karst Medium During a Rainy Event. In Hydrogeological and Environmental Investigations in Karst Systems, edited by Andreo B, Carrasco F, Durán JJ, Jiménez P, and LaMoreaux JW, Springer Berlin Heidelberg, 45-55.

Celle-Jeanton H, Emblanch C, Mudry J, Charmoille A (2003) Contribution of time tracers (Mg2+, TOC, delta C-13(TDIC), NO3-) to understand the role of the unsaturated zone: A case study - Karst aquifers in the Doubs valley, eastern France. Geophys. Res. Lett. 30(6): 1322.

Chalikakis K, Plagnes V, Guerin R, Valois R, Bosch FP (2011) Contribution of geophysical methods to karst-system exploration: an overview. Hydrogeology J. 19(6): 1169-1180.

Chalikakis K, Carrière SD, Mazzilli N, Danquigny C, Legchenko A, Emblanch C (2014) Water in karst hydrosystems unsaturated zone; MRS evidences within an integrated hydrogeophysical approach. Near Surface Geosciences 2014, 20th European Meeting of Environmental and Engineering Geophysics, 14-18 September, Athens Greece. Extended abstract TuPA110. 
Cognard-Plancq AL, Gevaudan C, Emblanch C (2006) Historical monthly rainfall-runoff database on Fontaine de Vaucluse karst system: review and lessons. In Karst, cambio climatico y aguas submediterraneas [Karst, climate change and submediterranean waters]. Duràn JJ, Andreo B, Carrasco F. Publicaciones del Instituto Geológico y Minero de España, 465-475.

540 Dahlin T (2001) The development of DC resistivity imaging techniques. Computers \& Geosciences 27(9): 1019-1029.

Dahlin T, Zhou B (2004) A numerical comparison of 2D resistivity imaging with 10 electrode arrays. Geophysical Prospecting 52(5): 379-398.

Davi H, Dufrêne E, Granier A, Le Dantec V, Barbaroux C, François C, Bréda N (2005) Modeling carbon and water cycles in a beech forest: Part II: Validation of the main processes from organ to stand scale. Ecological Modelling 185 (2-4): 387-405. doi: 10.1016/j.ecolmodel.2005.01.003.

Davi H, Dufrêne E, Francois C, Le Maire G, Loustau D, Bosc A, Rambal S, Granier A, Moors E (2006) Sensitivity of water and carbon fluxes to climate changes from 1960 to 2100 in European forest ecosystems. Agricultural and Forest Meteorology 141(1): 35-56.

550 Davi H, Baret F, Huc R, Dufrêne E (2008) Effect of thinning on LAl variance in heterogeneous forests. 551 Forest Ecology and Management 256(5): 890-899.

Deville S (2013) Caractérisation de la zone non saturée des karsts par la gravimétrie et l'hydrogéologie. [Gravimetric and hydrogeologic characterization of the karst unsaturated zone.] Thesis: Univ. de Montpellier II, $241 \mathrm{p}$.

Dufrêne E, Davi H, François C, Maire GI, Dantec VL, Granier A (2005) Modelling carbon and water cycles in a beech forest: Part I: Model description and uncertainty analysis on modelled NEE. Ecological Modelling 185 (2-4): 407-436. doi: 10.1016/j.ecolmodel.2005.01.004.

Emblanch C, Zuppi GM, Mudry J, Blavoux B, Batiot C (2003) Carbon 13 of TDIC to quantify the role of the unsaturated zone: the example of the Vaucluse karst systems (Southeastern France). J. of Hydrology 279 (1-4): 262-274. doi: 10.1016/s0022-1694(03)00180-x.

Fleury P, Plagnes V, Bakalowicz M (2007) Modelling of the functioning of karst aquifers with a reservoir model: Application to Fontaine de Vaucluse (South of France). J. of Hydrology 345 (1-2): 3849. doi: 10.1016/j.jhydrol.2007.07.014.

Ford DC, Williams PW (2007) Karst hydrogeology and geomorphology. Ed. Chapman and Hall.

Garry B (2007). Etude des processus d'écoulements de la zone non saturée pour la modelisation des acquifères karstiques. Expérimentation hydrodynamique et hydrochimique sur les sites du Laboratoire Souterrain à Bas Bruit (LSBB) de Rustrel et de Fontaine de Vaucluse. [Study of flow processes in the unsaturated zone for modeling karst aquifers. Hydrodynamic and hydrochemical experiments on the Underground Low-Noise Laboratory (LLBB) in Rustrel and the Fontaine de Vaucluse] Thesis: Univ. d'Avignon et des Pays de Vaucluse, $234 \mathrm{p}$.

Goldscheider, N, Drew D (2007) Methods in karst hydrogeology. London: Taylor and Francis, 264 p. (2010) Hydrogeology of the south-eastern Yucatan Peninsula: New insights from water level measurements, geochemistry, geophysics and remote sensing. J. of Hydrology 389 (1-2): 1-17. doi: 
Guglielmi Y (2010) Carbonate reservoirs - The Rustrel-Fontaine de Vaucluse LSBB: a unique facility for deep carbonate reservoir. Proceedings of I-Dust 2010, Apt, France - http://www.Isbb.eu.

Gunn J (2004) Encyclopedia of caves and karst science. Fitzroy, Dearborn, New York, 1940 p.

580

581

582

583

584

585

586

587

588

589

590

591

592

593

594

595

596

597

598

599

600

601

602

603

604

605

606

607

608

609

610

611

612

613

614

Halley RB, Schmoker JW (1983) High-porosity Cenozoic carbonate rocks of south Florida: progressive loss of porosity with depth. AAPG Bulletin 67 (2): 191-200.

Hartmann A, Lange J, Vivó Aguado À, Mizyed N, Smiatek G, Kunstmann H (2012) A multi-model approach for improved simulations of future water availability at a large Eastern Mediterranean karst spring. J. of Hydrology 468-469(0): 130-138.

Jacob T, Bayer R, Chery J, Jourde H, Le Moigne N, Boy JP, Hinderer J, Luck B, Brunet B (2008) Absolute gravity monitoring of water storage variation in a karst aquifer on the larzac plateau (Southern France). J. of Hydrology 359 (1-2): 105-117. doi: 10.1016/j.jhydrol.2008.06.020.

Jacob T, Chery J, Bayer R, Le Moigne N, Boy JP, Vernant P, Boudin F (2009) Time-lapse surface to depth gravity measurements on a karst system reveal the dominant role of the epikarst as a water storage entity. Geophysical J. International 177 (2): 347-360. doi: 10.1111/j.1365-246X.2009.04118.x.

Jacob T, Bayer R, Chery J, Le Moigne N (2010) Time-lapse microgravity surveys reveal water storage heterogeneity of a karst aquifer. J. Geophys. Res. 115 (B6): B06402. doi: 10.1029/2009jb006616.

Kaufmann O, Deceuster J (2014) Detection and mapping of ghost-rock features in the Tournaisis area through geophysical methods - an overview. Geologica belgica 17 (1): 17-26.

Kiraly L (1998) Modelling karst aquifers by the combined discrete channel and continuum approach. Bulletin d'Hydrogéologie 16: 77-98.

Labat D, Ababou R, Mangin A (2000 a) Rainfall-runoff relations for karstic springs. Part I: convolution and spectral analyses. J. of Hydrology 238 (3-4): 123-148. doi: 10.1016/s0022-1694(00)00321-8.

Labat D, Ababou R, Mangin A (2000 b) Rainfall-runoff relations for karstic springs. Part II: continuous wavelet and discrete orthogonal multiresolution. J. of Hydrology 238 (3-4): 149-178. doi: 10.1016/s0022-1694(00)00322-x.

Larocque M, Banton O, Ackerer P, Razack M (1999) Determining karst transmissivities with inverse modeling and an equivalent porous media. Ground Water 37 (6): 897-903. doi: 10.1111/j.17456584.1999.tb01189.x.

Leenhardt F (1883) Etude géologique de la région du Mont Ventoux. [Geologic study of the Mont Ventoux region] Paris: Masson, $273 \mathrm{p}$.

Legchenko A, Baltassat JM, Beauce A, Bernard J (2002) Nuclear magnetic resonance as a geophysical tool for hydrogeologists. J. of Applied Geophysics 50: 21-46.

Léonide P, Fournier F, Reijmer JJG, Vonhof H, Borgomano J, Dijk J, Rosenthal M, Van Goethem M, Cochard J, Meulenaars K (2014) Diagenetic patterns and pore space distribution along a platform to outer-shelf transect (Urgonian limestone, Barremian-Aptian, SE France). Sedimentary Geology 306(0): 1-23.

Mangin A (1975) Contribution à l'étude hydrodynamique des aquifères karstiques [Contribution to the hydrodynamic study of karst aquifers]. Thesis: Univ. de Dijon, France, 298p. 
Marsaud B (1996) Structure et fonctionnement de la zone noyée des karsts à partir des résultats expérimentaux. [Structure and functioning of the karst saturated zone based on experimental results] Thesis: Univ. Paris XI, Orsay, 305 p.

Martin N [2012] Ajustements fonctionnels du chêne vert (Quercus ilex L.) à la sécheresse à différentes échelles temporelles : Incidences sur la modélisation des processus. [Functional adjustments of the evergreen oak (Quercus ilex L.) to drought at different time scales: Effects on the modelling of the processes] Thesis: Univ. de Montpellier II, $239 \mathrm{p}$.

Masse JP (1969) Contribution a l'étude de I'Urgonien (Barrémien - Bédoulien) des Monts de vaucluse et du Luberon. [Contribution to the study of the Urgonian (Barremian-Bedoulian) of the Vaucluse and the Luberon mountains] Bureau de Recherches Géologiques et Minières, Orléan, $59 \mathrm{p}$.

Masse JP (1976) Les calcaires urgoniens de Provence ; Valanginien - Aptien inférieur ; Tome 1 : Stratigraphie - Paléontologie; Tome 2 : Les paléoenvironnements et leur évolution. [Urgonian Limestones of Provence; Valanginian - Lower Aptian; Volume 1: Statigraphy - Paleontology; Volume 2: Paleoenvironments and their evolution] Thesis: Univ. d'Aix-Marseille, $445 \mathrm{p}$.

Masse JP, Fenerci-Masse M (2011) Drowning discontinuities and stratigraphic correlation in platform carbonates. The late Barremian-early Aptian record of southeast France. Cretaceous Research 32(6): 659-684.

Maufroy E (2010). Caractérisation et modélisation numérique de l'effet de site topographique 3D : application à la Grande Montagne de Rustrel, Vaucluse. [Characterization and numerical modeling of 3D topographic site effects: application to the Grande Montagne of Rustrel, Vaucluse] Thesis: Univ. de Nice Sophia-Antipolis, $236 \mathrm{p}$.

Mazzilli N, Carrière SD, Chalikakis K, Legchenko A, Jourde H (2012) MRS applicability for the characterisation of the unsatured zone of karst hydrosystems. First results from the LSBB site (Rustrel, France). Proceedings of I-Dust 2012, Apt, France - http://www.Isbb.eu.

Mazzilli, N, Jourde H, Jacob T, Guinot V, Le Moigne N, Boucher M, Chalikakis K, Guyard H, Legchenko A (2013) On the inclusion of ground-based gravity measurements to the calibration process of a global rainfall-discharge reservoir model: case of the Durzon karst system (Larzac, southern France). Environmental Earth Science 68: 1631-1646. doi: 10.1007/s12665-012-1856-z.

Moussu F, Oudin L, Plagnes V, Mangin A, Bendjoudi H (2011) A multi-objective calibration framework for rainfall-discharge models applied to karst systems. J. of Hydrology 400 (3-4): 364-376. doi: 10.1016/j.jhydrol.2011.01.047.

Mudarra M, Andreo B (2010) Hydrogeological functioning of a karst aquifer deduced from hydrochemical components and natural organic tracers present in spring waters. The case of Yedra spring (southern Spain). Acta Carsologica 39 (2): 261-270.

Mudarra M, Andreo B, Mudry J (2012) Monitoring groundwater in the discharge area of a complex karst aquifer to assess the role of the saturated and unsaturated zones. Environmental Earth Sciences 65 (8): 2321-2336. doi: 10.1007/s12665-011-1032-x. model using multiple geophysical methods. 33rd GOCAD-MEETING, Nancy, France, 17-20 results. Proceedings of I-Dust 2010, doi: 10.1051/idust/201101001. 
680

681

682

683

684

685

686

687

688

689

690
Puig JM (1987) Le système karstique de la Fontaine de Vaucluse. [The karst system of the Fontaine de Vaucluse] Thesis: Univ. d'Avignon et des Pays de Vaucluse, 207p.

Rimmer A, Salingar Y (2006) Modelling precipitation-streamflow processes in karst basin: The case of the Jordan River sources, Israel. J. of Hydrology 331(3-4): 524-542.

Robert T, Caterina D, Deceuster J, Kaufmann O, Nguyen F (2012) A salt tracer test monitored with surface ERT to detect preferential flow and transport paths in fractured/karstified limestones. Geophysics 77 (2): B55-B67. doi: 10.1190/geo2011-0313.1

Scanlon BR, Mace RE, Barrett ME, Smith B (2003) Can we simulate regional groundwater flow in a karst system using equivalent porous media models? Case study, Barton Springs Edwards aquifer, USA. J. of Hydrology 276 (1-4): 137-158. doi: 10.1016/s0022-1694(03)00064-7.

Vouillamoz JM, Legchenko A, Albouy Y, Bakalowicz M, Baltassat JM, Al-Fares W (2003) Localization of saturated karst aquifer with magnetic resonance sounding and resistivity imagery. Ground Water 41 (5): 578-586. doi: 10.1111/j.1745-6584.2003.tb02396.x.

White, WB (2007) A brief history of karst hydrogeology: contributions of the NSS. J. Cave Karst Stud. (69): 13-26.

Worthington SRH (2009) Diagnostic hydrogeologic characteristics of a karst aquifer (Kentucky, USA). Hydrogeology J. 17(7): 1665-1678. doi: 10.1007/s10040-009-0489-0.

Worthington SRH, Ford DC (2009) Self-Organized Permeability in Carbonate Aquifers. Ground Water 47 (3): 326-336. doi: 10.1111/j.1745-6584.2009.00551.x.

Zhu JF, Currens JC, Dinger JS (2011) Challenges of using electrical resistivity method to locate karst conduits-A field case in the Inner Bluegrass Region, Kentucky. J. of Applied Geophysics 75 (3): $523-$ 530. doi: 10.1016/j.jappgeo.2011.08.009. 